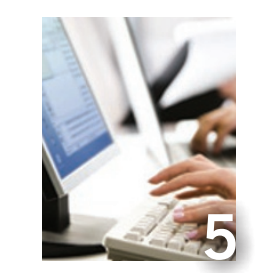

Choice words:

A survey finds that scientists self-censor when seeking grants

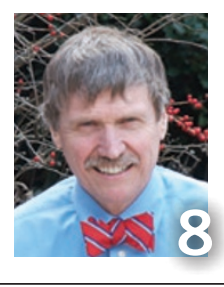

Man with a plan:

Mervyn Turner talks

about his role as

strategist at Merck

\title{
Challenges anticipated in removal of stem cell restrictions
}

Restrictions on federal funding of embryonic stem cell research in the US are expected to ease under the Obama administration. But broadening federal support for such research won't be as simple as rescinding the executive order signed by President George W. Bush in 2001 that imposed restrictions. Legal experts say that the best way to undo current restrictions is for Congress to act.

"A lot of people hope that, on January 21, President [Barack] Obama will stand behind a podium and announce that Bush's limitations on embryonic stem cell lines are gone and the next day everything with begin working in a much better way," says Larry Goldstein, director of the stem cell research program at the University of California, San Diego. But Goldstein adds that "even if that announcement comes, don't expect anything to happen quickly and without a lot more work."

In 1999, federal policy for funding embryonic stem cell research was formalized in a legal opinion issued by the general council for the US Department of Health and Human Services at the time, Harriet Rabb.

In short, the Rabb Opinion supported the idea that research on any embryonic stem cell lines could be federally funded (although it did not support funding for the actual derivation of those lines).

However, before the US National Institutes of Health (NIH) could provide funding, it needed to establish a set of standards and guidelines to accompany such grants - outlining, for example, acceptable origins for the cell lines. This process was not yet completed when President Bush announced his 2001 executive order, effectively nullifying the guidelines and enshrining the 60 stem lines that could be funded.

\section{Double trouble}

Bush's executive order has hobbled embryonic stem cell research. Of the 60 approved lines, only 21 have been shown to be viable for research.

Although nonfederal funds can be used to generate new embryonic stem cell lines, the executive order means that laboratories are required to keep their privately and publicly funded research entirely separate-creating

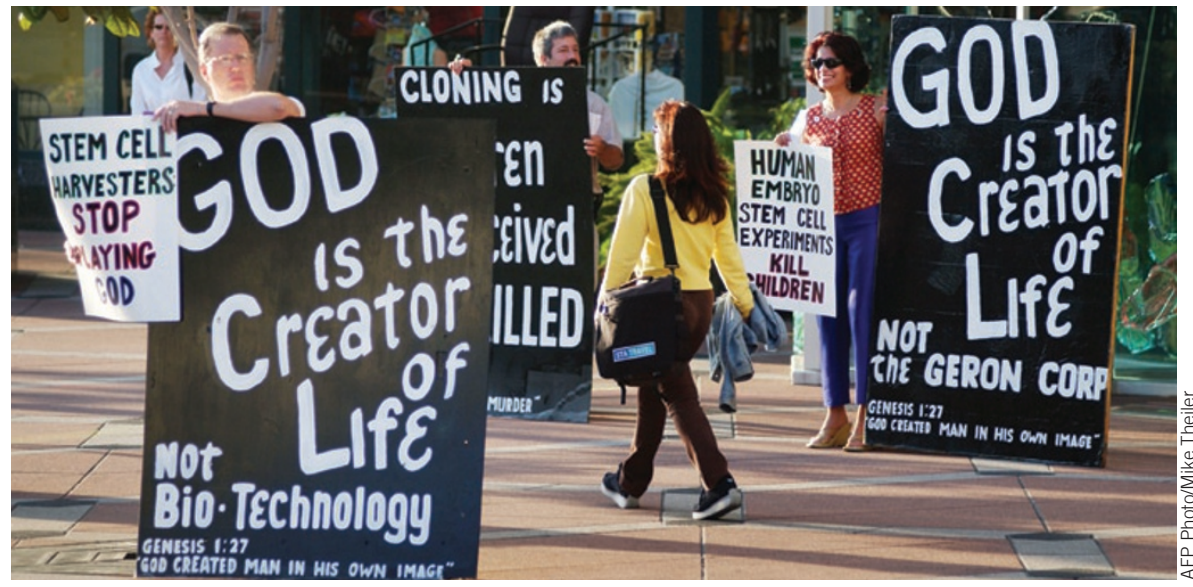

Back to the future: Undoing the restrictions put forth in 2001 might be tricky

extra costs because of the duplication of equipment and an administrative slog to document the separation of resources. Some researchers have gone as far as to create entirely separate laboratories for privately and publicly funded research.

"For the last eight years, we've had to worry about using the wrong pipette with the wrong sample, and just the cost in people's efforts has been draining," says George Daley, a researcher with the Harvard Stem Cell Institute and past president of the International Society for Stem Cell Research.

An executive order from Obama could, theoretically, unlock federal funding of new stem cell lines. But it will also probably face legal challenges.

Louis Guenin, a lecturer on ethics at Harvard Medical School, says that any rules that allow federal funds to go toward new embryonic stem cell lines might be at odds with the Dickey-Wicker Amendment, a rider on an appropriations bill that prohibits such federal grants to go toward research involving the destruction of human embryos. Embryonic stem cell lines typically originate from destroyed embryos.

\section{An act to follow}

The remedy, Guenin says, would be for Obama to instead push for legislation similar to the 2005 and 2007 Stem Cell Research Enhancement Acts, which specifically supported research of stem cell lines derived from embryos willingly given for research—while still not supporting the actual derivation of those lines or human cloning. Both acts passed in Congress with relative ease but were vetoed by President Bush. A sponsor of those bills, Democratic Congresswoman Diana DeGette, has publicly said that she already has a version queued for the new Congress. The idea is that such legislation would supersede the Dickey-Wicker Amendment.

Whatever the pathway, Story Landis, head of the NIH stem cell task force, says she expects that $\mathrm{NIH}$ funding priorities for stem cell research may shift if additional lines are allowed. The NIH currently funds $\$ 42$ million in embryonic stem cell research while providing five times as much to other stem cell research.

"I would expect that the other lines would make for new and exciting research possibilities that would be very competitive for NIH support," she says.

Researchers may also continue to explore ways to develop embryonic stem cell lines without destroying the source embryos, such as work reported in February 2008 in which single cells from blastocysts were coaxed into stem cell activity in the presence of other stem cells (Cell Stem Cell, doi:10.1016/j.stem.2007.12.013; 2008). However, many scientists don't expect such techniques to become widely used for the derivation of new stem cell lines.

Stu Hutson, Gainesville, Florida 